\title{
Bağımsız Denetim Standartları Kapsamında Bağımsız Denetim ve İç Kontrolün Etkileşimi*
}

\section{ÖZET}

Bağımsız denetim ve iç kontrol kavramları arasında önemli bir etkileşim olduğu düşünülmektedir. Bu çalışmada ilgili etkileşim; risk odaklı bağımsız denetim süreci takip edilerek, Kamu Gözetimi, Muhasebe ve Denetim Standartları Kurumu tarafından yayınlanan Bağımsız Denetim Standartları kapsamında ortaya konmaya çalışılmıştır. Çalışmada; nitel araştırma yaklaşımlarından içerik analizi yöntemi benimsenmiş olup, iç kontrol ve iç denetim kavramlarını ele alan bağımsız denetim standartları ve ilgili hükümleri detaylı olarak incelenmiştir. Yapılan incelemeler sonucunda, risk odaklı bağımsız denetim sürecinin özellikle ilk iki aşaması olan risk değerlendirme ve riske karşıllk verme aşamalarında etkileşimin yoğunluk kazandığ görülmektedir. Üst yönetimin iç kontrollere ilişkin sorumluluğu, yönetim ile kurulacak iletişim, iç denetim fonksiyonundan faydalanılması, önemli yanlışlı, hile riskleri ve iç kontrol yapısının değerlendirilmesi, iç kontrol sistemlerinin kurulmasl, prosedürlerin ve kontrollerin oluşturulması ve raporlamaya etkisi, iç kontrollerin etkinliğinin ve yeterliliğinin değerlendirilmesi, iç kontrol eksikliklerinin ve ihlallerinin belirlenmesi ve giderilmesi gibi önemli etkileşim konuları tespit edilmiştir.

Anahtar Kelimeler: Bağımsız Denetim ve İç Kontrolün Etkileşimi, Bă̆ımsız Denetim, Risk Odaklı Bă̆ımsız Denetim, İ̧ Kontrol, Bağımsız Denetim Standartları

JEL Sinıflandırması: M40, M42

\section{Interaction of External Audit and Internal Control Within the Scope of Auditing} Standards

\section{ABSTRACT}

It is thought that there is an essential interaction between the concepts of external audit and internal control. The relevant interaction in this study; risk-focused external auditing process was followed and tried to be set forth within the scope of Auditing Standards published by Turkish Public Oversight Accounting and Auditing Standards Authortiy. In the study; content analysis method, one of the qualitative research approaches, has been adopted, and the auditing standards and related provisions addressing the concepts of internal control and internal audit have been examined in detail. As a result of the examinations made, it is observed that the interaction is intensified especially in the first two stages of the riskfocused external audit process which are called risk assessment and response to risk. Important interaction issuees have been identifed such as; senior management's responsibilities related to internal controls, communication with management, utilizing the internal audit function, evaluate to the material misstatement and fraud risks and internal control structure, establishing internal control systems, establishing procedures and controls and their impact on reporting, evaluation of the effectiveness and adequacy of internal controls, identifying and remedying deficiencies and violations.

Keywords: Interaction Between External Audit and Internal Control, External Auditing, Risk-focused External Auditing, Internal Control, Auditing Standards

Jel Classification: M40, M42

* Bu çalışma Prof. Dr. Ümit GÜCENME GENÇOĞLU'nun danışmanlığında, Berna TEZ’in “Bağımsız Denetim ve İç Kontrol Sisteminin Etkileşimi: Sektörel Analiz” başlıklı doktora tezinden oluşturulmuştur.

Makale Gönderim Tarihi: 29.9.2020, Makale Kabul Tarihi: 11.10.2020, Makale Türü: Nitel Araştırma

** Öğr. Gör. Dr., Tekirdağ Namık Kemal Üniversitesi, Muratlı MYO, Muhasebe ve Vergi Uygulamaları Programı, bmadenli@nku.edu.tr, ORCID: 0000-0003-1309-1434. 


\section{GÍRİŞ}

Ekonomik, teknolojik ve sosyal açıdan günümüz dünyasının son derece hızlı bir değişim ve gelişim içinde olduğu, özellikle yaşanan değişimlerin nicel ve nitel olarak çeşitlilik arz ettiği görülmektedir. Bu çeşitlilik, benzer konularda çok farklı uygulamaları ve buna bağlı olarak birbirinden farklı sonuçları ortaya çıkarabilmektedir. Bu durum; her alandaki bilgi kullanıcılarının, ihtiyaç duyulan bilginin doğruluğuna ve güvenilirliğine şüphe ile yaklaşmalarına neden olabilmektedir. Doğru ve güvenilir bilginin ayıklanabilmesi ise, denetim ve kontrol faaliyetlerinin etkinliği ile mümkün olabilmektedir. Özellikle yaşanan finansal skandalların, denetim ve kontrol faaliyetlerinin önemini gidererek artırması nedeniyle; "bağımsız denetim" ve "iç kontrol” kavramlarının ön plana çıktığını söylemek mümkündür.

Ulusal ve uluslararası düzenlemeler dikkate alındığında öncelikle bağımsız denetim, akabinde iç kontrol kavramının ortaya çıktığı düşünülse de her iki kavramın birlikte gelişim gösterdiği görülmektedir. Amerika Birleşik Devletleri (ABD) ve Avrupa Birliği (AB) düzenlemeleri başta olmak üzere bağımsız denetime ilişkin düzenlemelerin çoğunda, işletmelerde iç kontrol sistemlerinin kurulması ve yürütülmesi ile ilgili hükümlere rastlanmaktadır. Özellikle günümüzde iç kontrol ve iç denetim kavramlarının, ulusal veya uluslararası düzeyde hazırlanan bağımsız denetim standartları içerisinde oldukça geniş bir şekilde ele alındığı görülmektedir. Bu nedenlerle geçmişten günümüze ilgili kavramlar arasındaki dirsek temasının güçlü bir etkileşimin göstergesi olduğu düşünülmektedir.

Bağımsız denetim ve iç kontrol üzerine yapılan çalışmalar incelendiğinde; çoğunlukla, iç kontrolün bağımsız denetim kalitesi üzerindeki etkileri ve iç kontrol sisteminin etkin çalışıp çalışmadığı gibi hususların araştırma konusu olduğu gözlemlenmiştir. Ancak bu iki kavram arasındaki çift yönlü etkinin mevzuatlar ve çeşitli düzenlemeler kapsamında ortaya konduğu çalışmaların oldukça az olduğu yapılan literatür incelemesi sonucunda tespit edilmiştir. Bu amaçla; ülkemizde Kamu Gözetimi, Muhasebe ve Denetim Standartları Kurumu (KGK) tarafından uluslararası denetim standartları benimsenerek hazırlanan Bağımsız Denetim Standartları (BDS) ve ilgili hükümleri nitel araştırma yaklaşımlarından içerik analizi yöntemi benimsenerek detaylı olarak incelenmiştir. İçerik analizi yöntemi kullanılarak; denetim standartları içerisinde, iç kontrol ve iç denetim kavramlarını ele alan veya atıf yapan ilgili hükümlerin vermek istedikleri mesajlar veya gizli kalmış anlamlar belirginleştirilmeye çalışılmış ve böylelikle bağımsız denetim ve iç kontrol arasındaki etkileşim konularının ortaya çıkartılması amaçlanmıştır. İlgili etkileşim konuları, risk odaklı bağımsız denetim süreci dikkate alınarak her bir aşama için ayrı ayrı belirlenmiştir.

\section{BAĞIMSIZ DENETIM VE İÇ KONTROL KAVRAMLARI}

\subsection{Denetim ve Kontrol Kavramları}

Latince işitme, dinleme anlamına gelen ve "audire" fiiline dayanan denetim (auditing) kavramı (Bozkurt, 2018: 23), çeşitli disiplinler tarafından farklı şekillerde tanımlanmaktadır. İşletme yönetimi açısından yönetim fonksiyonlarından sonuncusu olan denetim, işletme tarafından belirlenmiş standartlara uyulup uyulmadığının tespiti olarak ifade edilmektedir. $\mathrm{Bu}$ yönüyle denetim, işletmenin "amaçlara ulaşma derecesi" olarak tanımlanan etkililik (Yükçü ve Atağan, 2009: 2) düzeyinin saptanmasına yönelik yapılan çalışmalardan 
oluşmaktadır.(Akdemir, 2012: 279) Özellikle ABD'de Enron skandalı başta olmak üzere birçok ülkede ortaya çıkan finansal skandallar sonrasında, muhasebe alanında denetim kavramının önemi artmıştır. Kavram, ekonomik faaliyetler ve olaylarla ilgili iddialara ilişkin kanıtların toplandığı ve değerlendirildiği, bu iddialar ile belirlenmiş kriterler arasındaki uygunluk derecesinin tespit edildiği, iddialara dayanılarak hazırlanan raporlardaki sonuçların kullanıcılara iletildiği sistematik bir süreç olarak açıklanmaktadır.(Porter, 2003: 3)

Bununla birlikte iş dünyasında kimi zaman denetim kavramı ile karıştırıldığı ve hatta birbirlerinin yerine kullanıldığı görülen kontrol kavramı; her ne kadar "denetleme”, "yoklama, arama”, "bir şeyin gerçeğe ve aslına uygunluğuna bakma” (https://sozluk.gov.tr, 2020) olarak tanımlansa da, denetim kavramından ayrılmaktadır. İşletmenin amaçlarına zamanında, verimli bir şekilde ve eksiksiz olarak ulaşılıp ulaşılmadığının izlenmesi ve düzeltici önlemlerin alınması amacıyla yapılan faaliyetler (Yozgat, 1992: 339) olarak açıklanan kontrol kavramı, yönetimin alt fonksiyonlarından biridir. Kavram, yönetim fonksiyonlarının neyi, ne ölçüde ve nasıl yapması gerektiği ile gerçekleşen faaliyetleri karşılaştırarak bir sonuca varmaktadır. (İbiş ve Çatıkkaş, 2012: 97) Bu açıdan, ölçme ve değerlendirmelerin yapıldı̆̆ı bir süreç niteliği kazanmaktadır.(Dinçer, 1996: 278)

\subsection{Bağımsız Denetim}

Denetim tanımı içerisinde yer alan unsurların çeşitliliği ve zenginliği, kavramın alt başlıklara ayrılmasına neden olmuştur. $\mathrm{Bu}$ nedenle denetim kavramı "amaçlarına göre denetim”, “denetçinin statüsüne göre denetim” ve "sürekli-sınırlı denetim” olmak üzere üç ana gruba ayrılmaktadır. Denetimi amaçlarına göre sınıflandırdığımızda; finansal tabloların denetimi, uygunluk ve faaliyet denetimi olmak üzere üç denetim türünden bahsedilebilir. Denetçi statüsüne göre yapılan sınıflandırmaya göre denetim; kamu denetimi, iç denetim ve bağımsız denetim olarak üçe ayrılmaktadır.

Şirketlerin ve kamu kurumlarının finansal tablolarının denetimi olarak ifade edilen bağımsız denetim kavramı (Porter, 2003: 7), finansal tablolarının incelenmesini gerektirdiği için kimi kaynağa göre finansal tablo denetimi olarak da ifade edilmektedir.(Lessambo, 2018: 5-6) Ülkemizde 26.12.2012 tarihli 28509 Sayılı Resmi Gazetede yayınlanan "Bağımsız Denetim Yönetmeliği"ne göre bağımsız denetim; "finansal tablo veya diğer finansal bilgilerin, finansal raporlama standartlarına uygunluğu ve doğruluğu hususunda, makul güvence sağlayacak yeterli ve uygun bağımsız denetim kanıtlarının elde edilmesi amacıyla, denetim standartlarında öngörülen gerekli bağımsız denetim tekniklerinin uygulanarak defter, kaylt ve belgeler üzerinden denetlenmesi ve değerlendirilerek rapora bağlanması" olarak açıklanmaktadır. (KGK, Bağımsız Denetim Yönetmeliği, Resmi Gazete:28509, 2012: 4(1/b))

\section{3. İç Kontrol}

Yönetim fonksiyonları içerisinde yer alan planlama, örgütleme, yürütme, koordinasyon ve kontrol faaliyetlerinin günümüz işletmelerinin çoğunda hala verimli bir şekilde uygulanamadığı görülmektedir. Özellikle işletme yönetimlerince planlama ve örgütlemeye daha fazla önem verildiği ancak; yeterli ve nitelikli personel yoksunluğu, diş çevre koşullarında yaşanan ani değişimler, işletme politikalarında yaşanan değişimler vb. nedenlerle yürütme aşamasında planlardan sapmaların yaşandığı gözlemlenebilmektedir. Bu sapmaların ortaya çıkması koordinasyonun sağlanmasını zorlaştırmakta ve kontrol 
faaliyetlerinin önemini artırmaktadır. Bu nedenle kontrol kavramını, işletmenin ana sistemine bağlı ve iş akış süreçlerine etki eden bir yapı olarak değerlendirmek gerekmektedir. Günümüzde bu yapı "iç kontrol” olarak adlandırılmaktadır.

İç Denetçiler Enstitüsü (IIA- The Institute of Internal Auditors) tarafindan 1999 yılında yapılan tanıma göre iç kontrol; “...örgüt yönetiminin ayrılmaz bir parçası olup; faaliyetlerde etkinlik ve verimlilik, bütçenin uygulanması, finansal tablolar ile ilgili raporlar dahil olmak üzere finansal raporlama ve iç ile dış kullanıma ilişkin diğer raporların güvenilirliği, yürürlükteki yasalara ve düzenlemelere uygunluk amaçlarının gerçekleştirilmesi konusunda makul bir güvence sağlayan, organizasyon faaliyetlerinde devamlılık temelinde bir seri eylem ve aktivite olan mutlak olmayan fakat makul güvence sağlayan organizasyon yönetiminin önemli bir parçası"'(Demirbaş, 2005/1: 169) olarak ifade edilmektedir.

\subsection{Bağımsız Denetim ve İç Kontrol Kavramları Arasındaki İlişki}

Bağımsız denetim ve iç kontrol kavramları ile ilgili yapılan açıklamalardan hareketle, her iki kavramın birbirlerine önemli ölçüde etki ettiği görülmektedir. Bağımsız denetim kavramının giderek önem kazanması ile birlikte, işletmelerin iç kontrol ve iç denetim faaliyetlerinin bağımsız denetim kalitesine olumlu katkılar sağladığı ortaya çıkmıştır. Denetimin yapılacağı işletmenin seçiminden, denetimin planlanması ve programlanmasına, programın yürütülmesinden denetimin raporlanmasına kadar geçen süreçte; iç kontrol sistemi etkin çalışan işletmelerde yürütülen bağımsız denetim faaliyetlerinin daha verimli sonuçlandığını söylemek mümkündür. Kavramlar arasındaki ilişkiyi Şekil.1 yardımıyla açıklamak gerekirse, işletmelerin çeşitli risklere karşı kendilerini koruyabilecekleri üç savunma hattı olduğu ifade edilmektedir.

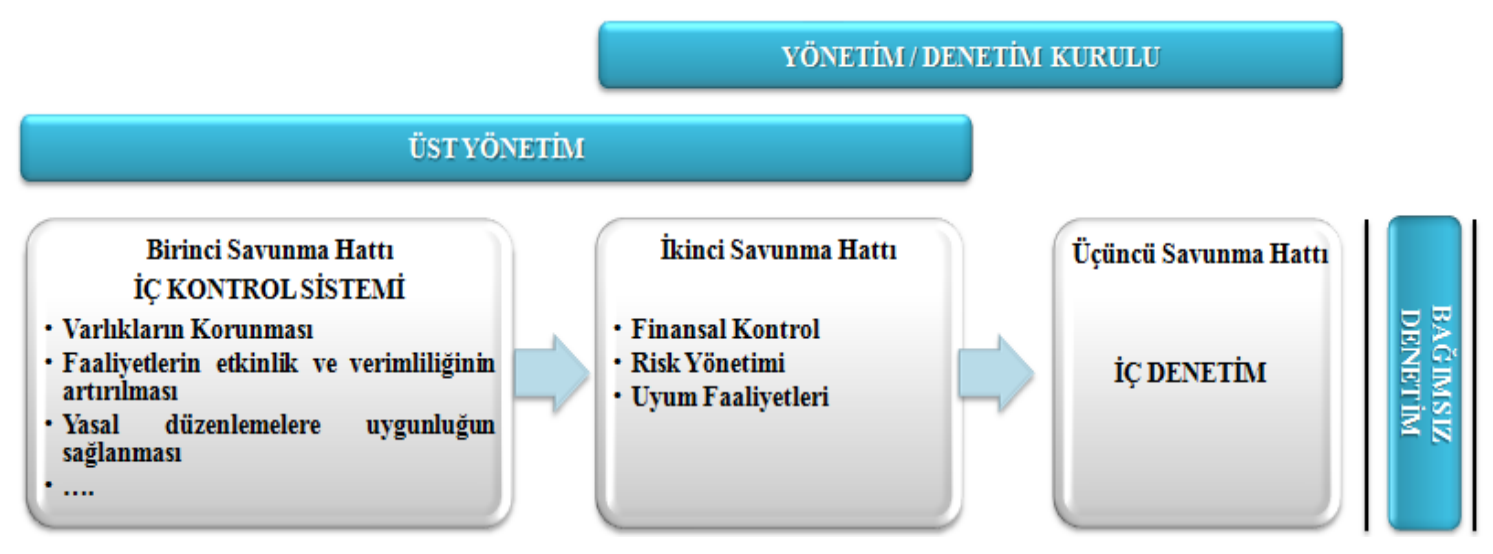

Şekil 1. Savunma Hattı Modeli

Kaynak: FERMA / ECIIA Guidance For Boards And Audit Committees, Guidance on the 8th EU Company Law Directive, Article 41, Monitoring The Effectiveness Of Internal Control, Internal Audit And Risk Management Systems, 21 September 2010, s.9 
Şekle göre; işletme varlıklarının korunması, faaliyetlerin etkinliğinin ve verimliliğinin artırılması, bilgi sistemlerinin güvenilirliğinin sağlanması, işlemlerin yasal düzenlemelere uygunluğunun güvence altına alınması gibi faaliyetleri içeren iç kontrol sistemi birinci savunma hattını oluşturmaktadır. İkinci savunma hatında ise finansal kontrol, risk yönetimi ve uyum faaliyetleri yer almaktadır. Birinci ve ikinci savunma hattı olarak belirtilen faaliyetlerin etkinliği konusunda güvence vermek, iç kontrol sisteminin eksikliklerini tespit etmek, gidermek ve sistemin gelişimine katkı sağlamak üçüncü savunma hattı olarak ifade edilen iç denetim faaliyeti kapsamında değerlendirilmektedir.(Yurtsever, 2015: 96) Bu üç savunma hattındaki faaliyetler, işletmenin üst yönetiminin gözetim ve denetiminde işletme içerisinde gerçekleştirilmektedir. Bağımsız denetim faaliyeti ise; finansal tablolarının doğruluğu ve güvenilirliği konusunda bir görüş oluşturmak amacı ile, bağımsız ve tarafsız kişiler tarafından yerine getirilmektedir. Denetim görüşünün doğrulu ise bağımsız denetim faaliyetinin kalitesine bağlıdır. Denetim faaliyetinin kaliteli olabilmesi için; işletme risklerinin doğru yönetilmesi, işletmenin iç kontrol sisteminin ve iç denetim fonksiyonun etkin çalışıyor olması gerekmektedir. İç kontrol sistemi ve iç denetim fonksiyonu etkin olmayan işletmelerde, bağımsız denetim faaliyeti oldukça zaman almakta, denetim riskleri yüksek düzeyde belirlenmekte ve yüksek maliyetler ortaya çıkmaktadır.

\section{RİSK ODAKLI BAĞIMSIZ DENETIM}

İşletmelerin karşı karşıya kaldıkları riskleri doğru bir şekilde yönetmesi gerektiğini savunan ve modern yönetim anlayışı olarak karşımıza çıkan kurumsal yönetim için, risk yönetimi olmazsa olmaz bir unsurdur ve öncelikle işletme içerisinde benimsenmelidir.(Türedi vd., 2015: 2) Ayrıca bağımsız denetim faaliyetinin tasarlanması, uygulanması ve sonuçlandırılması için de risklerin yönetilmesi büyük önem arz etmektedir. Sadece iç kontrollere odaklanmış bir denetimden ziyade riske odaklanmış bir denetimin işletmelere daha çok katma değer yarattı̆̆ına ilişkin bir paradigma ortaya çıkmıştır.(McNamee, 1997: 2223) Bağımsız denetim açısından risk odaklı denetim; müşteri işletmenin stratejik hedefleri dikkate alınarak, faaliyetlere ilişkin süreçlerin risk faktörü ile birlikte değerlendirilmesi gerektiğini ifade etmektedir.(Usul ve Mizrahi, 2016: 3-4)

Risk odaklı denetim yaklaşımı; iç kontrol sisteminin yeterliliğinin değerlendirilmesi, yönetimsel ve mali bilgi sistemlerinin gözden geçirilmesi, muhasebe kayıtları ile mali tabloların doğruluğu ve güvenilirliğinin incelenmesi(Kır, 2010: 55) gibi işlemleri gerektirdiği için; bağımsız denetim faaliyetinin yürütülmesinde, dört aşamalı geleneksel bağımsız denetim süreci yerine, Şekil.2'de görüleceği gibi üç aşamalı "risk odaklı bağımsız denetim süreci" takip edilmeye başlanmıştır. Buna göre; risk değerlendirme aşamasında risklerin tanımlanması, ölçülmesi ve önceliklendirilmesi amaçlanmaktadır.(McNamee, 1997: 22-23) Riske karşılık verme, sürecin ikinci aşaması olup ileri denetim prosedürlerinin tasarlanmasını ve uygulanmasını gerektirmektedir.(IFAC, 2018: 11) Raporlama aşamasında ise denetçi, elde ettiği bulguları, bu bulguların dayanağını ve bulgulardan hareketle varmış olduğu yargıyı raporlayarak ve bilgi kullanıcılarına ileterek bağımsız denetim faaliyetini sonuçlandırmaktadır. 


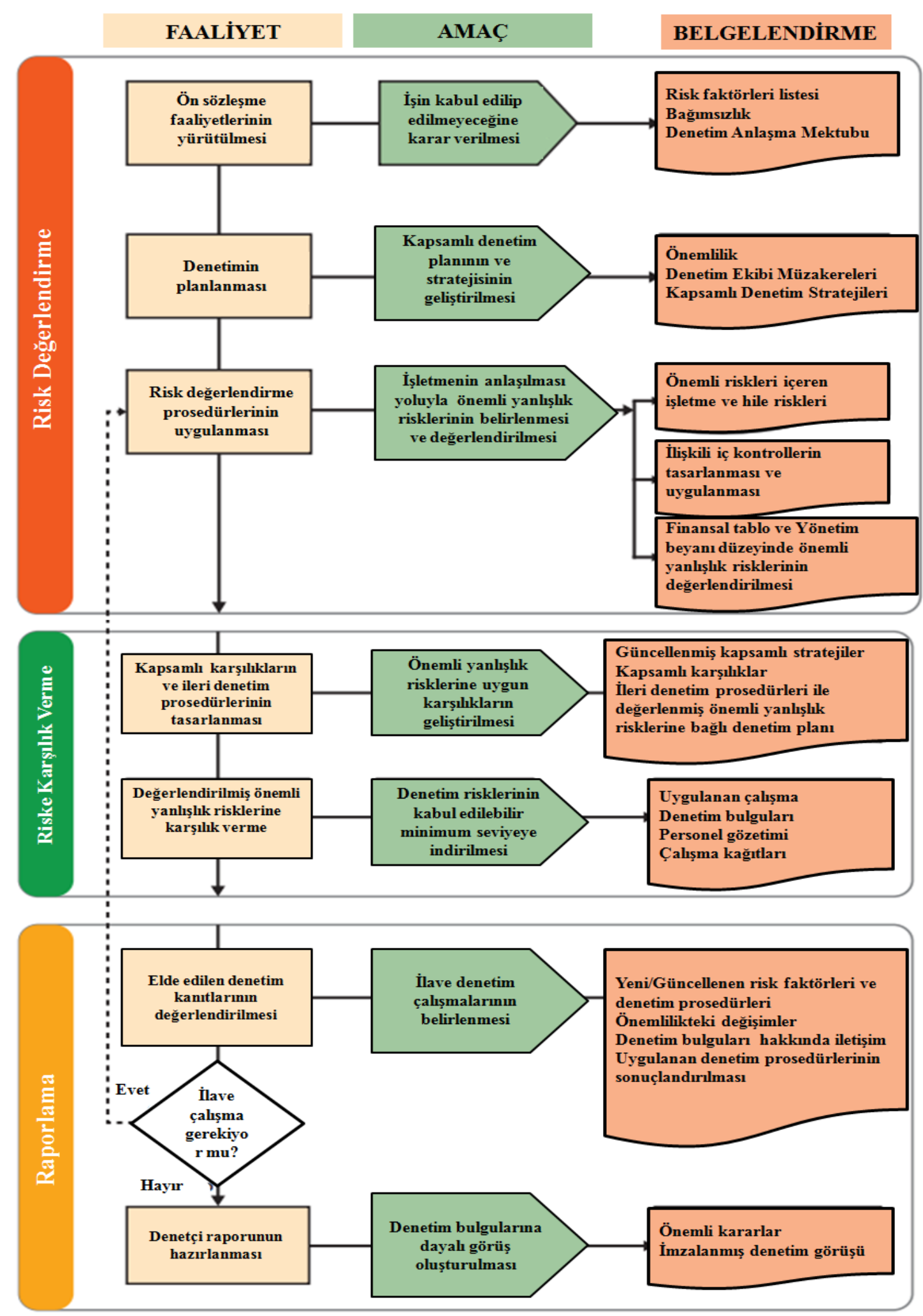

Şekil 2. Risk Odaklı Bağımsız Denetim Süreci

Kaynak: IFAC- International Federationof Accountants, Guide to Using ISA's in the Audits of Smalland Medium- Sized Entities, Volume:1, Core Concepts, Fourth Edition, 2018, s.11 


\section{BAĞIMSIZ DENETIM VE İÇ KONTROLÜN ETKILEŞİMINE İLIŞKIIN BAĞIMSIZ DENETIM STANDARTLARINDAKİ DÜZENLEMELER}

Bağımsız denetim ve iç kontrol kavramlarının ele alındığı, özellikle iç kontrolün etkinliğinin, bağımsız denetim kalitesi üzerindeki etkilerinin literatürde oldukça sık araştırıldığ görülmektedir. Oysaki iç kontrol ve bağımsız denetim kavramlarının geçmişten günümüze kadar birbirlerini çift yönlü olarak etkiledikleri ve paralel bir gelişim gösterdikleri gözlemlenmektedir. Dolayısıyla bu iki kavram arasında önemli bir etkileşim olduğu düşünülmektedir. $\mathrm{Bu}$ nedenle risk odaklı bağımsız denetim sürecinin her aşaması için bu kavramlar arasındaki karşılıklı etkileşim ile ilgili, Türkiye denetim standartları kapsamındaki düzenlemeler aşağıda ele alınıp açıklanmıştır.

\subsection{Risklerin Değerlendirilmesi Aşaması için Tespit Edilen Konular}

Bağımsız denetim standartları içerisinde yer alan temel ve açıklayıcı hükümlerin detaylı olarak incelenmesi sonucunda altı temel etkileşim konusu tespit edilmiş̧ir.

\subsection{1. Üst Yönetimin İç Kontrollere İlişkin Sorumluluğu}

Etkileşim alanlarından ilki; finansal tabloların hata ve hile kaynaklı önemli bir yanlışlık içermeyecek şekilde hazırlanabilmesi için işletme iç kontrollerinden, üst yönetimin sorumlu olmasıdır.(BDS 200, 4P., A.2(b)) Belirtilen sorumluluğun anlaşıldığı ve üstlenildiğine dair, bağımsız denetçi üst yönetiminden ön kabul niteliğindeki mutabakatı aldıktan sonra denetim sözleşmesini kabul etmektedir.(BDS 200, 4P., A.10) İlgili ön kabul, bazı ülkelerde kendi mevzuatlarında ayrıca belirtilmiş olabilmektedir. Bu durumda BDS'ler; mevzuatı hükümsüz kılmamakta ancak finansal tabloların hazırlanmasına veya buna yönelik iç kontrole ilişkin sorumluluğun denetçinin görevleri kapsamında değerlendirilmesini engellemektedir.(BDS 210, 6P(b), A.11) Yine BDS 200'e göre; bahsi geçen ilgili mutabakatın, işletme iç kontrolünün amacına ulaştı̆̆ veya eksiksiz olduğu yönünde denetçi tarafından tespitte bulunulduğu anlamını taşımadığı ifade edilmektedir. Bunun yanı sıra BDS'lere uygun yürütülmüş bir denetimin ihtiyaç duyulan iç kontrollerin yerini almadığı da belirtilmektedir.(BDS 210, 6P, A.17) İlgili hükümde özellikle vurgulanmak istenen; yönetim tarafindan verilen mutabakatın, iç kontrolün etkinliğine ilişkin bir beyanat değil de, yönetim olarak iç kontrole ilişkin sorumlulukların anlaşıldığı yönündeki bir beyanat olmasıdır.

Bazı durumlarda denetçi; işletme üst yönetimine, iç kontrole ilişkin sorumluluğun kapsamı hakkında çeşitli açıklamalarda bulunabilir.(BDS 210, 6P(b/ii), A.19) Bu açıklamalar; finansal tabloların hazırlanması ile ilgili kayıtlar, belgeler ve diğer hususlar vb. tüm bilgilere erişim imkânı sağlama, denetimin amacı doğrultusunda talep edilen ilave bilgileri sağlama, denetim kanıtlarının toplanması için işletme içinde gerekli görülen kişilerle kısıtlama olmaksızın görüşme imkânı sağlama vb. sorumlulukları içerebilmektedir.(BDS 210, 6P(b/iii))

Yönetimin iç kontrollere ilişkin sorumluluğunun yanı sıra; aynı zamanda bu iç kontrollerin sürekliliğinin sağlanması da yönetimin sorumlulukları arasında yer almaktadır.(BDS 210, 6P, A.16) Ayrıca bu sorumluluklara ilave olarak üst yönetimden sorumlu olanlar, gözetim faaliyetinden de sorumlu olmaktadır. Buna göre; finansal raporlama faaliyetlerinin güvenilirliğini, işletme faaliyetlerinin etkinliği ve verimliliğini, faaliyetlerin mevzuata uygun olarak yürütülmesi için uygun iç kontrolün tasarlanmasını, uygulanmasını ve 
sürdürülmesini, üst yönetimden sorumlu olanlar yönetimin gözetimi kapsamında temin etmek durumundadır.(BDS 260, 3P., A.33)

BDS 210'a göre; işletme üst yönetimi finansal tabloların onaylanması ve iç kontrol sisteminin izlenmesine ilişkin sorumluluklarını üstlenebilecekleri gibi halka açık işletmelerde bu sorumluluklar denetim komitesi vb. alt komitelere de aktarlabilmektedir. (BDS 210, 6P., A.12)

\subsubsection{Yönetim ve Üst Yönetimden Sorumlu Olanlarla Kurulacak İletişim}

Bağımsız denetim ve iç kontrolün etkileşimini ortaya koyan diğer bir standart ise BDS 260 "Üst Yönetimden Sorumlu Olanlarla Kurulacak İletişim" standardıdır. Denetçi; finansal tabloların denetiminde üst yönetimden sorumlu olanlarla etkin ve karşılıklı iletişim kurarak, kapsamlı bir çerçeve sunmak ve kişilere bildirilecek bazı özel hususları belirlemek zorundadır.(BDS 260, 3P., A.33) Ayrıca iletişimin şekil, zamanlama ve içeriği ile ilgili üst yönetim bilgilendirilmektedir. İç denetim fonksiyonuna sahip bir işletmede üst yönetimin bilgilendirilmesinden önce iç denetçi ile müzakere yapilabilmektedir. (BDS 260, 18P., A.42) Üst yönetimden sorumlu olanlarla kurulacak iletişimde dikkat edilmesi gereken bir diğer konu ise uygun kişi veya kişilerin belirlenmesidir. (BDS 260, 11P., A.4)

Bazı standartlarda ifade edildiği gibi bağımsız denetçi tarafından belirlenen, ciddi işletme riskleri dahil olmak üzere denetim planının kapsamının ve zamanlamasının üst yönetimden sorumlu olanlara bildirilmesi gerektiği BDS 260'ta da ele alınmaktadır. Standart, iç denetim fonksiyonuna sahip olan işletmelerde; iç ve dış denetçilerin uyumları, denetimde iç denetçilerin kullanımının niteliği ve boyutlarına ilişkin üst yönetimden sorumlu olanlarla görüş alışverişi yapılmasını hükmetmektedir. Burada ortaya çıkan etkileşim, işletme üst yönetiminden sorumlu olanların; iç kontrolün önemine ilişkin farkındalıkları, tutumları ve iç kontrol sisteminin etkinliğine dair gözetimleri ile ilgilidir. (BDS 260, 15P., A.13,14)

Denetçi tarafindan üst yönetimden sorumlu olanlara bildirilecek önemli hususlardan bir tanesi ise iç kontrol eksiklikleridir. Bu eksikliklerin üst yönetime yazılı olarak bildirilmesi gerektiği ifade edilmekle birlikte, işletmedeki önemli yanlışlık risklerini en aza indirebilmek amacıyla denetçi ilk olarak sözlü bildirimde de bulunabilmektedir. (BDS 265, 9P., A.14) Hizmet kuruluşu kullanan bir işletmenin denetçisi de, tespit ettiği ve muhakemesine göre yönetimin dikkatini çekecek kadar önemli gördügü eksiklikleri yönetime ve üst yönetimden sorumlu olanlara zamanında yazılı olarak bildirmek zorundadır. (BDS 402, 17P.(ç), A.39) Üst yönetimden sorumlu olanlar ve yönetim ile kurulacak iletişimi etkileyen faktörlerden birisi ise, ana şirket ve bağlı şirketler topluluğunun özellikleridir. Şirketler topluluğu ve bağlı işletmelerin denetiminde, denetim ekibinin birim denetçileri, topluluk üst yönetimi ile koordineli bir şekilde çalışmalıdır. Bu noktada uyulması gereken çeşitli yükümlülükler mevcut olup, ilgili yükümlülükler birim denetçisine talimat mektubu ile iletilmektedir. (BDS 600, 40P., A.58, Ek.5) Ayrıca topluluğa bağlı birim denetçisinden; birim düzeyinde "önemli yanlışlık" doğuran ve birim yönetimi veya çalışanlarının dahil olduğu hile vb. önemli iç kontrol eksikliklerini topluluk denetim ekibine iletmesi beklenmektedir. (BDS 600, 41P.(f/g)) 


\subsection{3. İç Kontrol Yapısının Değerlendirilmesi}

Bağımsız denetim ile iç kontrol arasındaki belki de en önemli etkileşim alanlarından biri, bağımsız denetçinin işletme ve çevresini tanımak amacıyla yaptığı, işletme iç kontrol yapısının nasıl şekillendiğine ilişkin değerlendirmeleridir. BDS 210'a göre; işletmeler iç kontrollerini şekillendirirken, yönetimin ihtiyaçlarını, faaliyetlerin karmaşıklığını, maruz kalınan risklerin niteliğini ve mevzuatı dikkate almak durumundadırlar. (BDS 210, 6P., A.18)

BDS 315'te ise iç kontrol kavramına yer verilerek "finansal raporlamanın güvenilirliği, faaliyetlerin etkinliği ve verimliliği ile ilgili mevzuata uygunluk açısından işletmenin amaçlarına ulaştığına dair makul güvence sağlamak amacıyla üst yönetimden sorumlu olanlar, yönetim ve diğer personel tarafindan tasarlanan, uygulanan ve sürekliliğ $i$ sağlanan süreç" (BDS 315, 4P.(b)) olarak tanımlanmaktadır. Ayrıca BDS 315'te; kontrol çevresi, risk değerlendirme süreci, finansal raporlamayla ilgili bilgi sistemi ve iletişim, denetimle ilgili kontrol faaliyetleri ve kontrollerin izlenmesi olarak sınıflandırılmış iç kontrol bileşenleri ile ilgili hükümler ve açıklamalar yer almaktadır. (BDS 315, 5P., A.1)

Risk değerlendirme aşamasında bağımsız denetçi en faydalı bilgileri, işletmenin iç kontrol yapısı ile ilgili incelemeleri sırasında elde edebilmektedir. Denetçinin iç kontrol yapısını tanımaya yönelik yürüttüğü faaliyetler; işletmenin önemli yanlışlık risklerini etkileyen faktörlerin belirlenmesine, denetim prosedürlerinin nitelik, kapsam ve zamanlama açısından tasarlanmasına yardımcı olmaktadır. (BDS 315, 12P., A.50)

İşletme hedeflerine ulaşılmasını engelleyecek risklere yönelik olarak işletme içerisinde çeşitli kontrollerin tasarlanması, uygulanması ve sürdürülmesi iç kontrolün temel amacını oluşturmaktadır. İşletmenin büyüklüğü ve faaliyetlerin karmaşıklığı, iç kontrolün bu amacına yönelik olarak tasarlanmasını etkileyen faktörler arasında yer almaktadır. (BDS 315, 12P., A.52) Denetçi, işletmenin iç kontrol yapısını değerlendirirken bu hususları dikkate almak durumundadır. Ayrıca iç kontrol sistemi etkin işliyor olsa bile, bazı yapısal kısıtlamalar nedeniyle sistem makul güvence sağlayamamaktadır. Subjektif yargılara dayanarak alınan hatalı kararlar veya insan hatasından dolayı etkisiz kalan iç kontroller gibi yapısal kısıtlamaların neler olduğunun denetçi tarafından tespit edilmesi ve değerlendirilmesi gerekmektedir. (BDS 315, 12P., A.54)

İç kontrol kısıtlarının bazıları işletmenin büyüklüğünden etkilenmektedir. Özellikle küçük işletmelerde iç kontrol sisteminin daha basit bir yapıya sahip olduğunu, bu nedenle yönetici konumundaki işletme sahiplerinin iç kontroller üzerinde etkilerinin fazla olduğunu söylemek mümkündür. Bu durum iç kontrollerin ihlal edilmesi olasılığını artıracağ 1 için önemli yanlışlık risklerinin belirlenmesi sırasında denetçinin dikkate alması gereken bir unsur olarak değerlendirilebilmektedir. (BDS 315, 12P., A.58)

BDS 315, denetim faaliyetlerinin yürütülmesi sırasında iç kontrolün farklı açılardan denetimi nasıl etkileyebileceği ile ilgili denetçinin değerlendirme yapmasını zorunlu tutmaktadır. $\mathrm{Bu}$ bağlamda standart, iç kontrolün; kontrol çevresi, işletmenin risk değerlendirme süreci, finansal raporlamaya ilişkin ilgili iş süreçleri dahil bilgi sistemi ve iletişim, kontrol faaliyetleri ve kontrollerin izlenmesi olmak üzere beş bileşene ayrılarak değerlendirilmesi gerektiğini ifade etmektedir. (BDS 315, 12P., A.59) İlgili standartta iç kontrol bileşenleri ayrı ayrı ele alınmaktadır. 


\section{* Kontrol Çevresi ile İlgili Hususlar}

İç kontrol bileşenlerinden ilki olan kontrol çevresi, üst yönetimden sorumlu olanların ve işletme yönetiminin iç kontrollerin önemine ilişkin farkındalıklarını ve tutumlarını ortaya koymaktadır. (BDS 315, 14P., A.77,78,81) Denetçi, işletme yönetimini ve çalışanlarını sorgulayarak yönetimin etik davranışlara ilişkin yazılı kurallar oluşturup oluşturmadığına, bu kurallara uyup uymadığına ilişkin tutumuna ve bu alandaki iç kontrollerin uygulanıp uygulanmadığına dair bilgi elde etmektedir. Ayrıca iç denetim fonksiyonunun, iç kontrole ilişkin tespit ettiği eksikliklere yönelik yönetimin karşılık verip vermediği veya nasıl karşılık verdiği de ele alınmaktadır. (BDS 315, 14P., A.79,80)

\section{* $\quad$ Risk Değerlendirme Süreci ile İlgili Hususlar}

İç kontrolün ikinci bileşeni olan risk değerlendirme süreci, yönetimin alacağı kararlara dayanak oluşturması nedeniyle BDS 315'te detaylı olarak ele alınmaktadır. Denetçinin; işletmenin finansal raporlama faaliyeti ile ilişkili risklerin ve bu risklerin önemini belirlemesi, risklerin gerçekleşme ihtimallerini değerlendirerek ilgili risklere karşı atılacak adımların olup olmadığını saptaması gerekmektedir. İşletmenin risk değerlendirme sürecinin olduğu ve risklere karşı atılacak adımların belirli olduğu tespit edilmişse, bu durumda denetçinin sürecin sonuçlarına ilişkin kanaat edinmesi beklenmektedir. Bununla birlikte önemli yanlışlık risklerinin süreç tarafindan tespit edilmesi bekleniyorken tespit edilemediği durumda denetçi, işletme şartlarının uygun olup olmadığı, iç kontrol sisteminde önemli bir eksiklik olup olmadığı ile ilgili kanat edinmektedir. (BDS 315, 15P., 16P., A.88) Aynı zamanda işletme koşulları dikkate alınarak risk değerlendirme sürecinin olmamasının uygun olup olmadığı ve bu hususun önemli bir iç kontrol eksikliğine neden olup olmadığının değerlendirilmesi gerekmektedir. (BDS 315, 17P., A.89)

\section{* Kontrol Faaliyetleri ile İlgili Hususlar}

Yönetimin beyanı düzeyindeki önemli yanlışlık risklerinin değerlendirilebilmesi, kontrol faaliyetleri hakkında gerekli bilgilerin toplanmasına bağlıdır. İç kontrol sisteminin üçüncü bileşeni olan kontrol faaliyetlerine ilişkin bilgi toplanmasındaki temel amaç, denetim prosedürlerini tasarlamaktır. Standart; denetçinin işletmedeki her bir kontrol faaliyetini anlamak yerine, önemli yanlışlık risklerinin yüksek olabileceği alanlardaki kontrol faaliyetleri üzerine yoğunlaşmasını yeterli bulmaktadır. (BDS 315, 20P., A.99) Kontrol faaliyetlerine ilişkin olarak denetçinin kanaat edinebilmesi; faaliyetlerin sadece ilişkili risklerle değil aynı zamanda sistem ve süreçlerle birlikte değerlendirilerek anlaşılmasını ve yönetimin buna ilişkin beyanatları ile ilişkilendirilmesini gerektirmektedir. Özellikle ciddi risklerin mevcudiyetinde kontrol faaliyetleri ve ilgili risklere ilişkin kontroller hakkında denetçinin bir yargıya varması önem arz etmektedir. (BDS 315, 26P.(c), 29P., A.137)

\section{* Bilgi Sistemleri ve İletişim ile İlgili Hususlar}

Finansal raporlamaya ilişkin bilgi sistemleri ve iletişim iç kontrol sisteminin dördüncü bileşeni olarak karşımıza çıkmaktadır. Bağımsız denetçi; işletmenin finansal tabloları için önem arz eden işlem sınıfları, işlemlerin nasıl başlatıldığı, kaydedildiği, düzeltildiğgi, aktarıldığı, hangi bilgi teknolojilerinin kullanıldı $\breve{1}$, manuel sistemlerdeki prosedürlerin neler olduğu, finansal raporlama sürecinin nasıl olduğu, standart olmayan işlemlere veya 
düzeltmelere ilişkin yevmiye kayıtlarının nasıl tutulduğu ile ilgili bilgiler toplayarak işletme bilgi sistemi hakkında bir yargıya varmaya çalışmaktadır. (BDS 315, 18P.)

\section{* Kontrollerin İzlenmesi ile İgili Hususlar}

İç kontrolün son bileşeni olan kontrollerin izlenmesi hususunda denetçi; finansal raporlama ile ilgili işletmenin iç kontrollerini nasıl izlediğini, bu amaçla hangi temel faaliyetleri kullandığını, kontrol eksiklikleri ile ilgili iyileştirici adımları nasıl başlattığını araştırmaktadır. İç kontrol sisteminin performans etkinliğinin ölçüldüğü bu süreçte, iç kontrollerin etkinliği zamanında değerlendirilerek gerekli iyileştirici adımlar atılmaktadır. (BDS 315, 22P., A.110)

\subsection{4. Önemli Yanlışık Risklerinin Değerlendirilmesi}

Bağımsız denetim ile iç kontrolün etkileştiği en önemli noktalardan bir diğeri “önemli yanlışlık” risklerinin değerlendirilmesi ile ilgilidir. Önemli yanlışlık risklerinin belirlenerek denetçi tarafından gerekli değerlendirmenin yapılması, bağımsız denetim sürecinin ikinci aşaması olan risklere karşılık verme aşamasında gerekli işlerin tasarlanmasına ve uygulanmasına dayanak oluşturmaktadır. (BDS 315, 3P.)

Denetçi işletmeyi ve çevresini tanıyabilmek için, işletmenin amaçları ve stratejileri hakkında bilgi toplamak ve önemli yanlışlık risklerine neden olabilecek iş hayatındaki riskleri tespit etmek zorundadır. (BDS 315, 11P.(ç), A.41,42) Önemli yanlışlık riskleri yapısal risk ve kontrol risklerinden oluşmaktadır. Kontrol riskleri "bir işlem sınıfi, hesap bakiyesi veya açıklamalara ilişkin bir yönetim beyanında ortaya çıkabilecek ve tek başına veya diğer yanlışlıklarla birlikte önemli olabilecek bir yanlışlı̆̆ın, işletmenin iç kontrolü tarafindan zamanında önlenememesi veya tespit edilerek düzeltilememesi riski” (BDS 200, 13P.(h/ii)) olarak tanımlanmaktadır.

Standartlar işletme yönetiminden veya üst yönetimden sorumlu olanlardan; finansal tabloların hazırlanmasına yönelik amaçlara ulaşılmasını tehdit edebilecek her türlü riski belirleme, buna bağlı olarak gerekli iç kontrolleri tasarlama, uygulama ve sürdürme konusunda etkin olmalarını beklemektedir. (BDS 200, 5P., A.34,39,41) Denetçi risk değerlendirmesi yapabilmek için risk değerlendirme prosedürlerini doğru belirlemek zorundadır. Standart; finansal tablo ve yönetim beyanı düzeyinde önemli yanlışlık risklerinin belirlenmesi ve değerlendirilmesi amacıyla uygulanması gereken denetim prosedürlerini, risk değerlendirme prosedürleri olarak açıklamaktadır. (BDS 315, 4P.(ç)) Ancak bu risk değerlendirme prosedürlerinin tek başına denetçinin görüşüne dayanak oluşturacak yeterli sayıda ve uygun denetim kanıtı sağlamayacağı ve bu prosedürlerin neler olduğu standartta açıkça belirtilmektedir. (BDS 315, 5P., 6P.(a/b/c)) Bununla birlikte iç kontrolün yapısal kısıtlamaları dahil olmak üzere denetimin kendi yapısal kısıtlamalarına bağlı olarak bazı önemli yanlışlıkların tespit edilemeyebileceği, bu yönde kaçınılmaz bir riskin mevcut olduğu gerçeği gibi hususların denetim sözleşmesinde yer verilmesi gerektiği BDS 210'da ifade edilmektedir. (BDS 210, 10P., A.24)

Dışarıdan hizmet alımı yapan bir işletmenin bağımsız denetiminde denetçi; özellikle "önemli yanlışlık" risklerinin belirlenmesi ve değerlendirilmesinde alınan hizmetin niteliğini, önemini ve bu hizmetlerin iç kontrol yapısına olan etkilerini anlamaya çalışmak 
durumundadır. (BDS 402, 7P.(a/b)) Denetimin yürütüleceği işletme, bir topluluk işletmesi de olabilmektedir. Toplulukların bağımsız denetiminde görev alan denetim ekibi; iç denetim fonksiyonunun birimler ve topluluk bazındaki faaliyetleri ile öz değerlendirmelerine ilişkin kontrollerin nasıl izlendiğine, topluluk finansal tablolarında hile kaynaklı "önemli yanlışlık" risklerinin belirlenmesinde kullanılan bilgilerin neler olduğuna ilişkin değerlendirmeler yapmak zorundadır. (BDS 600, 17P., A.23,27)

\subsubsection{Hile Riskleri}

Bağımsız denetim ve iç kontrolün etkileştiği bir diğer konu hile riskleri ile ilgilidir. BDS 240'ta; işletme yönetiminin, finansal tabloların hile kaynaklı önemli bir yanlışlık içerip içermediğine yönelik yaptıkları risk değerlendirmeleri dahil olmak üzere bu değerlendirmelerin niteliğinin, kapsamının ve sıklı̆̆ının bağımsız denetçiler tarafından sorgulanması gerektiği hükmü yer almaktadır. Örneğin işletme yönetiminin önemli yanlışlık risklerine ilişkin herhangi bir değerlendirme yapmamış olması, denetçinin bu durumu, iç kontrole önem verilmediğinin bir göstergesi olarak değerlendirilmesine neden olmaktadır. (BDS 240, 18P.(a), A.13)

İşletme yönetiminin risk değerlendirmeleri yönünden sorgulanmasının yanı sıra BDS 240 ayrıca; iç denetim fonksiyonuna sahip işletmelerde, hileye veya şüphelenilen bir duruma ilişkin iç denetim fonksiyonunun bilgisinin olup olmadığı hakkında fonksiyondaki ilgili kişilerin de sorgulanmasını zorunlu tutmaktadır. Bağımsız denetçi bu doğrultuda, iç denetim fonksiyonun hilenin tespitine yönelik prosedürleri uygulayıp uygulamadığı ve bu prosedürlere bağlı olarak elde edilen bulgulara işletme yönetiminin yeterli karşıllk verip vermediği hususlarını değerlendirmektedir. (BDS 240, 20P., A.19) İşletme yönetiminin icrai görevler almadığı durumda denetçi; hile risklerinin belirlenmesi ve karşılık verilmesine ilişkin yönetim tarafindan izlenen süreçlerin, oluşturulan iç kontrollerin üst yönetimden sorumlu olanlar tarafından nasıl gözlemlendiğine ilişsin kanaat edinmek zorundadır. (BDS 240, 21P., A.20)

İşletmede etkin işleyen bir iç denetim fonksiyonunun mevcut olması, hile risklerinin ortaya çıkmasını engelleyen önemli bir unsur olarak değerlendirilebilir. (BDS 240, 25P., A.27) Hile riskleri ile ilgili etkileşim konularından sonuncusu ise; denetçi tarafından, üst yönetimin sorumluluğunun anlaşıldığına dair mutabakat dışında ayrıca hile risklerine ilişkin de bir beyanat alınmak zorundadır. (BDS 240, 40P.(a/c))

\subsection{6. İç Denetim Fonksiyonundan Faydalanılması}

BDS 300'e göre denetimin planlanması sırasında denetçi tarafından çeşitli denetim stratejileri oluşturulmaktadır. $\mathrm{Bu}$ stratejileri belirlerken denetçi; işletmede iç denetim fonksiyonunun bulunup bulunmamasını, fonksiyonun çalışmalarının kullanılıp kullanılmayacağını veya hangi ölçüde kullanılabileceğini, iç kontrolün etkinliğine yönelik önceki denetim sonuçlarını, iç kontrolün tasarımı, uygulanması ve sürdürülmesi ile ilgili yönetimin taahhütlerini dikkate almak durumundadır. (BDS 300, 8P., A.9)

Bağımsız denetçi iç denetim fonksiyonunun çalışmalarından hangi alanlarda faydalanılacağı ve bunun kapsamının ne olacağına karar verirken, fonksiyonun çalışmalarının niteliğini, kapsamını, genel denetim stratejileri ve denetim planı açısından ihtiyaca uygun olup olmadığını dikkate almak durumundadır. Bu nedenle denetçi, çalışmaların öncelikle 
denetim stratejisi ve planına uygun olup olmadığını belirlemektedir. (BDS 610, 17P., A.15,16)

Denetçi iç denetim fonksiyonu bulunan işletmelerde, fonksiyonun yürüttügü, yürüteceği faaliyetler ve iç kontrol yapısı dahil olmak üzere sorumlulukları ve bunların niteliği hakkında bilgi elde etmeye çalışmaktadır. Fonksiyonun finansal raporlamaya yönelik sorumlulukları; işletmenin riskleri nasıl yönettiği, iç kontrol yapısının nasıl olduğu, kurumsal yönetimin etkinliğini sağlayabilmek adına yönetime ve üst yönetimden sorumlu olanlara güvence sağlayan prosedürlerin nasıl uygulandığı ve sonuçların nasıl değerlendirildiğini içermektedir. Finansal raporlama ile ilgili olmayan sorumlulukları ise faaliyetlerin verimliliğinin, etkinliğinin ve ekonomikliğinin değerlendirilmesi olarak karşımıza çıkmaktadır. (BDS 315, 23P., 24P., A.113,114,115,119,121)

İç denetim fonksiyonundan faydalanılması, işletmenin iç denetçisinin veya iç denetim fonksiyonunun yürütülmesinden sorumlu olan kişilerin denetim ekibi içerisinde yer aldığ1 anlamına gelmemektedir. Nitekim BDS 220'ye göre denetim ekibi; “sorumlu denetçi, bă̆ımsız denetçiler ve diğer personel ile denetim şirketi veya denetim ă̆ına dahil şirket tarafindan görevlendirilen denetimle ilgili prosedürleri uygulayan diğer kişiler" olarak açıklanmaktadır. Bağımsız denetçilerin faydalandığı veya faydalanacağı dış uzmanlar ile iç denetim fonksiyonunda yer alan ve denetime doğrudan yardım sağlayan kişilerin denetim ekibine dahil edilmeyeceği standartlarda açıkça ifade edilmektedir. (BDS 220, 7P.(d))

İç denetim fonksiyonunun kurumsal statüsü ile politika ve prosedürlerin iç denetçinin tarafsızlığını desteklemediği, fonksiyonun gerekli yeterliliğe sahip olmadığı ve sistematik ve disiplinli bir yaklaşım uygulamadığı gibi fonksiyonun kalitesine yönelik risklerin yüksek olduğu ve ilgili çalışmaların denetim kanıtı olarak kullanmanın uygun olmadığı tespit edilirse, bağımsız denetçi iç denetim fonksiyonunun çalışmalarını kullanmama kararı verecektir. (BDS 610, 16P.(a/b/c), A.12,13) İç denetim fonksiyonunun çalışmalarının kullanılması genel denetim stratejinin bir parçası olduğu için denetçi, çalışmaları nasıl ve hangi ölçüde kullanılacağını işletme üst yönetiminden sorumlu olanlara bildirmek zorundadır. (BDS 610, 19P., 20P., 21P., 32P., A.23,25) Fonksiyon tarafından üst yönetimden sorumlu olanlara raporlanmış bir çalışma ve dış denetçi tarafından alınan karar ile ilgili olan denetim prosedürlerinin uygulanmasında, doğrudan yardım almak amacıyla iç denetçiler kullanılamaz. (BDS 610, 30P.)

İç denetim fonksiyonunun çalışmalarının kullanılması haricinde denetçi işletme ve çevresini tanırken yeterli denetim kanıtı toplayabilmek için bazı durumlarda muhasebe ve denetim dişındaki alanlarda uzman kişilere de ihtiyaç duyabilmektedir. (BDS 620, 7P., A.4)

Tüm değinilen konuların yanı sıra risk değerlendirme aşamasında, denetçinin tam set finansal tabloların denetiminden sorumlu olup olmaması açısından da etkileşim söz konusu olabilmektedir. Denetçinin tam set finansal tabloların denetiminde de görevli olup olmadiğına bakılmaksızın, tek bir finansal tablonun veya ilgili tablodaki bir unsurun denetiminde, denetimle ilgili tüm standartlara uyulması zorunludur. Denetçi tam set finansal tablo denetiminden sorumlu değilse, sette yer alan tek bir finansal tablonun veya tablo unsurlarının standartlara uygun olarak denetiminin mümkün olup olmadığını değerlendirmek durumundadir. (BDS 805, 7P., A.6) 


\subsection{Riske Karşııı Verme Aşaması İçin Tespit Edilen Konular}

Bağımsız denetim ile iç kontrolün etkileștiği noktalardan biri, risklere karşıllk uygulanacak denetim prosedürlerinin tasarlanması sırasında karşımıza çıkmaktadır. Etkin bir kontrol çevresine sahip işletmelerde bağımsız denetçinin, işletmenin iç kontrol sistemine ve dolayısıyla bu sistem içerisinden elde edilmiş olan denetim kanıtlarına güven düzeyi yüksek olmaktadır. Bu durumda denetçi, bazı denetim prosedürlerini dönem sonu uygulamak yerine ara dönemde uygulamayı tercih etmektedir. (BDS 330, 5P., A.2) Bunun yanı sira finansal tabloların raporlanmasında mevzuata uygunluğun gözetimi üst yönetimin sorumluluğunda olduğu için; denetçi, işletmede uygun iç kontrollerin tasarlanıp tasarlanmadığı veya politika ve prosedürlerin iç denetim fonksiyonu tarafindan uygulanıp uygulanmadığı ile ilgili de denetim prosedürleri tasarlamak zorundadır. (BDS 250, 3P., A.2) Denetim prosedürlerinin niteliği, risklerin değerlendirilmesinde dikkate alınan gerekçelere bağlı olarak belirlenmektedir. Örneğin, risklerin değerlendirmesinde kontrol risklerinin ve ilişkili iç kontrollerin dikkate alınıp alınmadığının ve işletmenin iç kontrollerinin etkinliğine ilişkin denetim kanıtı elde edilmesinin gerekip gerekmediğinin denetçi tarafından değerlendirmesi gerekmektedir. (BDS 330, 7P.(a/ii))

Kanıtların elde edilmesi amacıyla denetçi; tetkik, gözlem, dış teyit, yeniden hesaplama, yeniden uygulama, analitik prosedürler ve sorgulama gibi çeşitli denetim prosedürlerini kullanabilmektedir. (BDS 500, 6P., A.20) Örneğin, finansal tablolar açısından stokların önemli olduğu kanaatine ulaşılmışsa, denetçi uygun ve yeterli kanıt toplamak amacıyla stoklara ilişkin iç kontrollerin niteliği hakkında bilgi elde edebilecek şekilde fiziki stok sayımına katılmayı uygun bulabilmektedir. (BDS 501, 4P.(a), 8P.(b), A.3,16) Baz1 durumlarda denetçi dış teyit prosedürlerini uygulayabilmektedir. İşletme kayıtları ile teyit eden üçüncü tarafın sunduğu bilgiler arasındaki farklılık olarak ifade edilen istisnalar, işletmenin finansal raporlamaya ilişkin iç kontrol eksikliklerinin bir göstergesi olarak düşünüldüğü için, denetçinin istisnaları bir yanlışlık göstergesi olup olmadığını araştırması gerekmektedir. (BDS 505, 6P.(2), 14P., A.21)

Denetçinin; iç kontrol yapısındaki bir aksaklıktan, işletmenin sıklıkla kullandığı uygun olmayan varsayımlardan veya değerleme yöntemlerinden dolayı ortaya çıkan ve münferit olmayan yanlışlıkları tespit etmesi durumunda, genel denetim stratejilerinin ve denetim planının revize edilip edilmeyeceğine ilişkin karar vermesi gerekmektedir. (BDS 450, 6P.(a), A.7) İşletmenin iç kontrol yapısı dahil işletme ve çevresine ilişkin edinilen bilgiler, denetçinin yeterli ve uygun denetim kanıtı elde edip etmediğine ilişkin yargısını etkilemektedir. Denetçi yeterli ve uygun denetim kanıtı elde ettiği yönünde bir yargıya ulaştıktan sonra, kanıtların finansal tablolardaki yönetim beyanlarını doğrulayıp doğrulamadığına veya bu beyanlarla çelişip çelişmediğine bakmaksızın elde ettiği tüm denetim kanıtlarını mütalaa etmek durumundadır. (BDS 330, 26P., A.62)

Denetim faaliyetinin yürütüldüğü işletme hizmet alan bir işletme ise, bağımsız denetçi uygun ve yeterli denetim kanıtı elde edip etmediğini değerlendirirken, hizmet kuruluşunun denetçisi tarafindan uygulanan kontrol testlerinin ve bu testlerin sonuçlarının işletmenin finansal tablolarındaki yönetim beyanları ile ilgili olup olmadığını incelemek zorundadır. (BDS 402, 17P.(ç)) 
Finansal tablolardaki yönetim beyanlarına ilişkin elde edilen kanıtları desteklemek amacıyla denetçi; işletme yönetiminden veya üst yönetimden sorumlu olanlardan, tüm iç kontrol eksikliklerinin veya iç kontrolde önemli görevleri bulunan kişilerin karıştığ şüphelenilen hilelere ilişkin bilgilerin kendisine bildirildiğine dair yazılı bir beyanat alabilmektedir. (BDS 580, 13P., A.11, Ek.2) Faaliyetlerini ilişkili tafralarla gerçekleştiren bazı işletmelerde yönetim tarafindan konu hakkında denetçiye herhangi bir açıklama yapılmamış olması durumunda; denetçi, iç denetim fonksiyon raporları başta olmak üzere çeşitli kayıt ve belgeleri tetkik etmeyi tercih etmektedir. (BDS 550, 14P., 15P., A.16,17,22)

Riske karşılık verme aşamasında karşılaşılan bir diğer etkileşim alanı ise örnekleme olarak ifade edilmektedir. Bağımsız denetçinin kontrol testlerini uygulayabilmesi için örnekleme yöntemi kullanılır. Denetçi örnekleme yöntemini kullanırken; çeşitli istatistiki teknikler ve mesleki muhakemesini kullanarak, örnekleme risklerini minimum seviyeye indirecek örneklem büyüklüğünü tespit etmek zorundadır. (BDS 530, 5P.(g/ ̆ㅡ), 7P., A.11, Ek.2, Ek.3)

Yine bu aşamada ortaya çıkan etkileşim konularından biri ise; maddi doğrulama prosedürleri sonucunda belirlenmiş yanlışlıkların, iç kontrollerin etkinliği ile ilgili olup olmadığının değerlendirilmesine yöneliktir. Aynı zamanda maddi doğrulama prosedürleri sonucunda herhangi bir yanlışlık tespit edilmemiş olması, iç kontrollerin etkin olduğuna dair bir denetim kanıtı sağlamamaktadır. (BDS 330, 16P., A.40)

Denetim prosedürlerinin ve kanıtlarının önemli yanlışlık risklerine ilişkin uygunluğunun devam edip etmediğinin gözden geçirilmesi sırasında denetçi, tespit edilmiş iç kontrol eksikliklerine yönelik zamanında karşılık verilmemesi gibi hile ihtimaline işaret eden durumları da değerlendirmektedir. Denetçi özellikle iç kontrol eksikliklerinin uygun bir biçimde ele alınmaması ve gerekli karşılıkların verilmemesi hususunda üst yönetimle görüşmek zorundadır. (BDS 240, 35P., 36P., 37P., 38P., A.50,66, Ek.3)

Risklere karşılık verme aşamasında karşılaşılan son etkileşim konusu ise çalışma kağıtları ile ilgilidir. Denetçi çalışma kağıtlarını; denetim prosedürlerinin zamanlamasını, kapsamını ve niteliğini, uygulanan denetim prosedürlerinin sonuçlarını ve elde edilen kanıtları, denetim sırasında ortaya çıkan önemli hususlar ve bunlara ilişkin sonuçları, yaptı̆̆ muhakemeleri kendisiyle herhangi bir bağlantısı olmayan tecrübeli bir denetçinin anlayacağ şekilde hazırlamalıdır. (BDS 230, 8P., 12P., A.17,19(a) - BDS 200, 22P., A.74)

\subsection{Raporlama Aşaması İçin Tespit Edilen Konular}

Raporlama aşamasındaki en önemli etkileşim konusu, bağımsız denetçinin denetim faaliyeti sonucunda ulaştığı denetim görüşüdür. Bağımsız denetim faaliyetinin tanımından hareketle bağımsız denetçi; finansal tabloların tüm önemli yönleriyle, geçerli finansal raporlama çerçevesine uygun olarak hazırlanıp hazırlanmadığı ve gerçeğe uygun bir görünüm sağlayıp sağlamadığı ile ilgili görüş bildirmek zorundadır.

Denetçi raporunda görüş dışında, yönetim ve üst yönetimden sorumlu olanların finansal tablolara ilişkin sorumluluklarını içeren “... finansal tabloların/konsolide finansal tabloların TMS'lere uygun olarak hazırlanmasından, gerçeğe uygun bir biçimde sunumundan ve hata ve hile kaynakl önemli yanlışlık içermeyecek şekilde hazırlanması için gerekli gördü̈̆̈̈ iç kontrolden sorumludur." ifadesine de yer verilmektedir. Bununla birlikte bağımsız 
denetçinin bağımsız denetime ilişkin sorumlulukları kapsamında “... bir görüş bildirmek amacıyla değil ama duruma uygun denetim prosedürlerini tasarlamak amacıyla denetimle ilgili iç kontrol değerlendirilmektedir." ifadesi denetim raporunda yer almaktadır.

Raporda iç kontrol eksikliklerine ilişkin olarak ise "Diğer hususların yanı sıra, denetim sırasında tespit ettiğimiz önemli iç kontrol eksiklikleri dahil olmak üzere, bă̆ımsız denetimin planlanan kapsamı ve zamanlaması ile önemli denetim bulgularını üst yönetimden sorumlu olanlara bildirmekteyiz" ifadesine yer verilmektedir. (BDS 700, 20P., 39P.(b), A.19,50, Ek.Örnek1-2)

Bağımsız denetçi iç kontrol eksiklikleri ile denetim faaliyetinin tüm aşamalarında karşı karşıya gelebilmektedir. Özellikle hızlı önlem almayı gerektirmeyecek nitelikteki yapısal iç kontrol eksikliklerinin yönetim kademesine iletilmesi genellikle raporlama aşamasında olmaktadır. Denetçi, tespit ettiği iç kontrol eksikliklerini yönetim kademesinde iç kontrol alanını iyi bilen ve eksiklikleri düzeltme yetkisine sahip kişilerle müzakere edebilir. (BDS 265, 7P., A.1)

Denetçi; tespit edilen eksikliklerin gelecekte finansal tablolarda önemli bir yanlışlığa yol açma ihtimaline, eksikliğe neden olan varlık veya borçların zarar ve hileye açık olma durumuna, muhasebe tahminlerinin subjektif ve karmaşık olup olmamasına, iç kontrol eksikliklerinden etkilenmeye müsait olan hesap bakiyeleri, işlem sınıfları, faaliyet hacimlerine ilişkin tutarların önemine, eksikliklerin diğer iç kontrol eksiklikleri ile etkileşimine bakarak edindiği kanaat doğrultusunda görüşünü şekillendirmektedir. (BDS 265, 8P., A.6)

Bağımsız denetçi tarafından iç kontrol eksikliklerinin üst yönetimden sorumlu olanlara yazılı olarak raporlanması veya bildirilmesi bu eksikliklerin önemini ortaya koymakla birlikte üst yönetimin gözetim sorumluluğunu yerine getirmesine yardımcı olmaktadır. (BDS 265, 9P., A.12,13) Bununla birlikte daha önceki denetimler sırasında üst yönetime bildirilmiş olan önemli iç kontrol eksikliklerine yönelik olarak herhangi bir düzeltici işlem yapılmadığ denetçi tarafından tespit edilirse, eksikliklerinin giderilmemesine yönelik mantıklı bir gerekçe olup olmadığ 1 değerlendirilmek zorundadır. Mantıklı bir gerekçenin olmamasını başlı başına bir iç kontrol eksikliği olarak ele almaktadır. (BDS 265, 9P., A.17) Eğer iç kontrol eksikliklerinin işletme yönetimi tarafından maliyet nedeniyle giderilmediği ya da iç denetim fonksiyonu veya düzenleyici kurumlar tarafından ilgili eksikliklerin daha önceden bildirildiği tespit edilmişse, denetçi ilgili eksiklikleri tekrar bildirmek zorunda değildir. (BDS 265, 10P.(b), A.22,24)

Denetim raporlarında, uzun yıllar denetçinin belirtmek istediği konular "diğer hususlar/ dikkat çekilen hususlar / açıklayıcı paragraf" gibi başlıklar altında ele alınırken; 2017 yılından itibaren ülkemizde bu tür hususların "kilit denetim konuları" başlı̆̆ 1 altında bildirilmesi gerektiği zorunlu tutulmuştur. Denetçi kilit denetim konularını belirlerken; işletme yönetimi tarafından hazırlanan faaliyet raporlarını, finansal durum değerlendirme raporlarını, yönetim kurulu raporlarını, işletmenin kurumsal yönetim beyanını, iç kontrol ve risk değerlendirme raporlarını da dikkate almak durumundadır. (BDS 701, 13P., A.38) Örneğin; iç kontrol ve risk değerlendirme amacıyla hazırlanan raporlar yıllık faaliyet raporunun bir parçası olarak değerlendirildiği için kilit denetim konularının belirlenmesinde bu tür raporlar denetçiye faydalı bilgiler sağlayabilmektedir. (BDS 720, 12P.(a/aT), A.3) Denetçi bazı durumlarda özel amaçlı finansal tablolar üzerine de bağımsız denetim gerçekleştirebilmektedir. (BDS 800, 11P., A.13, Ek.Örnek.1) Kimi zaman denetçi sadece tek bir finansal tablo ile ilgili veya finansal tablodaki belirli bir unsura ilişkin de görüş 
bildirebilmektedir. (BDS 805, 11P., A.17, Ek.2, Örnek.3) Her iki durumda da denetçi, hazırlayacağı raporda yönetimin gerekli iç kontrollerden sorumlu olduğunu belirtmek durumundadir.

\section{SONUÇ}

KGK tarafından yayınlanan bağımsız denetim standartlarının incelenmesi sonucunda bağımsız denetim ve iç kontrol kavramlarının etkileşim gösterdiği alanlar, risk odaklı bağımsız denetim sürecinin her aşaması için belirlenmeye çalışılmıştır. Buna göre, risk değerlendirme aşamasında: üst yönetimin iç kontrollere ilişkin sorumluluğu, yönetim ve üst yönetimden sorumlu olanlarla kurulacak iletişim, iç kontrol yapısının değerlendirilmesi, önemli yanlışlık risklerinin değerlendirilmesi, hile riskleri, iç denetim fonksiyonundan faydalanılması olarak ifade edilen konularda etkileşimin ortaya çıktığı tespit edilmiştir. Riske karşılık verme aşamasında etkileşimin ortaya çıktığı alanlar; uygun iç kontrol sistemlerinin kurulması, prosedürlerin ve kontrollerin oluşturulması ve riske karşılık verilmesi, iç kontrol etkinliğinin ve yeterliliğinin değerlendirilmesi, iç kontrol eksikliklerinin veya ihlallerinin belirlenmesi olarak özetlenebilir. Raporlama aşaması olarak adlandırılan son aşamada ise; işletme yönetiminin iç kontrol eksikliklerini gidermesi, eksikliklerin finansal tablolarda yaratacağı önemli yanlışlıkların belirlenmesi, varlık veya borçların hileye açıklığı, kontrol faaliyetlerinin raporlamaya etkisi, iç kontrol faaliyet ve risk değerlendirme raporlarının hazırlanması önemli etkileşim alanları olarak belirlenmiştir.

\section{KAYNAKLAR}

Akdemir, Ali (2012), İşletmeciliğin Temel Bilgileri, 2. Baskı, Ekin Yayınevi, Bursa

Bozkurt, Nejat (2018), Muhasebe Denetimi, 8. Baskı, Alfa Yayınları, İstanbul

Demirbaş, Mahmut (2005/1), “İç Kontrol Ve İç Denetim Faaliyetlerinin Kapsamında Meydana Gelen Değişimler”, İstanbul Ticaret Üniversitesi Sosyal Bilimler Dergisi, Say1:7, Y11:4, ss.167-188

Dinçer, Ömer (1996), İşletme Yönetimi, 1.Baskı, Beta Basım Yayım, İstanbul

Ferma/Ec11a Guidance For Boards And Audit Committees, (21 September 2010), Monitoring The Effectiveness Of Internal Control, Internal Audit And Risk Management Systems. Guidance On The 8th Eu Company Law Directive, Art.41

Https://Sozluk.Gov.Tr , 28.09.2020

IFAC- International Federationof Accountants. (2018), Guide To Using Isa's İn The Audits Of Small-And Medium- Sized Entities, 4.Bask1, Volume:1, Core Concepts

İbiş Cemal-Çatıkkaş Özgür (2012), “İşletmelerde İç Kontrol Sistemine Genel Bakış”, Sayıştay Dergisi, Sayı: 85, ss.95-121

Kır, Hüseyin (2010), “Stratejik Denetim Ve Denetimde Risk Odakl1lık”, Denetişim, Sayı:4, ss.47-61 
Lessambo, Felix. I. (2018), Auditing, Assurance Services, And Forensics. Palgrave Macmillan. Https://Doi.Org/10.1007/978-3-319-90521-1

Mcnamee, David (1997), “Risk-Based Auditing, Internal Auditor”, Vol:54, Issue: 4, pp.22-26

Porter, Brenda (2003), Principles Of External Auditing, Second Edition, John Wiley \& Sons Ltd., İngiltere

Türedi, Hasan - Zor, Ümmügülsüm - Gürbüz, Filiz (2015), "Risk Odaklı İç Denetim" Muhasebe Ve Finansman Dergisi, Sayı: 66, ss.1-20

Usul, Hayrettin - Mizrahi, Rozi (2016), Risk Odaklı Denetim, 1.Baskı, Detay Yayıncılık, Ankara

Yozgat, Osman (1992), İşletme Yönetimi, 1.Baskı, Nihad Sayar Eğitim Vakfı Yayınları No:435, İstanbul

Yurtsever, Gürdoğan (2015), “İç Denetimin Fonksiyonları Ve Katma Değer”, Finans Politik \& Ekonomik Yorumlar, Cilt: 52, Say1:602, S-ss.89-101

Yükçü, Süleyman - Atağan Gülşah (2009), “Etkinlik, Etkililik Ve Verimlilik Kavramlarının Yarattığı Karışıklık”, Atatürk Üniversitesi İktisadi Ve İdari Bilimler Dergisi, Cilt: 23, Say1:4, ss.1-13

BDS 200 Bağımsız Denetçinin Genel Amaçları ve Bağımsız Denetimin Bağımsız Denetim Standartlarına Uygun Olarak Yürütülmesi, 13/10/2013 tarihli ve 28794 sayılı Resmi Gazete (Güncel versiyonu için bakınız www.kgk.gov.tr)

BDS 210 Bağımsız Denetim Sözleşmesinin Şartları Üzerinde Anlaşmaya Varılması, 14/11/2013 tarihli ve 28821 sayılı Resmi Gazete (Güncel versiyonu için bakınız www.kgk.gov.tr)

BDS 220 Finansal Tabloların Bağımsız Denetiminde Kalite Kontrol, 14/11/2013 tarihli ve 28821 sayılı Resmi Gazete (Güncel versiyonu için bakınız www.kgk.gov.tr)

BDS 230 Bağımsız Denetimin Belgelendirilmesi, 14/11/2013 tarihli ve 28821 sayılı Resmi Gazete (Güncel versiyonu için bakınız www.kgk.gov.tr)

BDS 240 Finansal Tabloların Bağımsız Denetiminde Bağımsız Denetçinin Hileye İlişkin Sorumlulukları, 10/12/2013 tarihli ve 28847 sayılı Resmi Gazete (Güncel versiyonu için bakınız www.kgk.gov.tr)

BDS 250 Finansal Tabloların Bağımsız Denetiminde İlgili Mevzuatın Dikkate Alınması, 10/12/2013 tarihli ve 28847 sayılı Resmi Gazete (Güncel versiyonu için bakınız www.kgk.gov.tr)

BDS 260 Üst Yönetimden Sorumlu Olanlarla Kurulacak İletişim, 10/12/2013 tarihli ve 28847 sayılı Resmi Gazete (Güncel versiyonu için bakınız www.kgk.gov.tr) 
BDS 265 İç Kontrol Eksikliklerinin Üst Yönetimden Sorumlu Olanlara ve Yönetime Bildirilmesi, 12/12/2013 tarihli ve 28849 say1l Resmi Gazete

BDS 300 Finansal Tabloların Bağımsız Denetiminin Planlanması, 30/12/2013 tarihli ve 28867 sayılı Resmi Gazete (Güncel versiyonu için bakınız www.kgk.gov.tr)

BDS 315 İşletme ve Çevresini Tanımak Suretiyle “Önemli Yanlışlık” Risklerinin Belirlenmesi ve Değerlendirilmesi, 30/12/2013 tarihli ve 28867 sayılı Resmi Gazete (Güncel versiyonu için bakınız www.kgk.gov.tr)

BDS 330 Bağımsız Denetçinin Risk Olarak Değerlendirilmiş Hususlara Karşı Yapacağı İşler, 24/12/2013 tarihli ve 28861 sayılı Resmi Gazete (Güncel versiyonu için bakınız www.kgk.gov.tr)

BDS 402 Hizmet Kuruluşu Kullanan Bir İşletmenin Bağımsız Denetiminde Dikkate Alınacak Hususlar. 30/12/2013 tarihli ve 28867 say1lı Resmi Gazete

BDS 450 Bağımsız Denetimin Yürütülmesi Sirasında Belirlenen Yanlışlıkların Değerlendirilmesi, 31/12/2013 tarihli ve 28868 sayılı Resmi Gazete (Güncel versiyonu için bakınız www.kgk.gov.tr)

BDS 500 Bağımsız Denetim Kanıtları, 30/12/2013 tarihli ve 28867 sayılı Resmi Gazete (Güncel versiyonu için bakınız www.kgk.gov.tr)

BDS 501 Bağımsız Denetim Kanıtları- Belirli Kalemler İçin Dikkate Alınması Gereken Özel Hususlar, 10/01/2014 tarihli ve 28878 say1lı Resmi Gazete

BDS 505 Dış Teyitler, 30/12/2013 tarihli ve 28867 sayılı Resmi Gazete

BDS 530 Bağımsız Denetimde Örnekleme, 22/01/2014 tarihli ve 28890 say1lı Resmi Gazete

BDS 580 Yazılı Beyanlar, 29/01/2014 tarihli ve 28897 sayılı Resmi Gazete (Güncel versiyonu için bakınız www.kgk.gov.tr)

BDS 600 Özel Hususlar - Topluluk Finansal Tablolarının Bağımsız Denetimi (Topluluğa Bağlı Birim Denetçilerinin Çalışmaları Dahil), 20/02/2014 tarihli ve 28919 sayılı Resmi Gazete (Güncel versiyonu için bakınız www.kgk.gov.tr)

BDS 610 İç Denetçi Çalışmalarının Kullanılması, 14/02/2014 tarihli ve 28913 sayılı Resmi Gazete

BDS 620 Uzman Çalışmalarının Kullanılması, 31/01/2014 tarihli ve 28899 sayılı Resmi Gazete

BDS 700 Finansal Tablolara İlişkin Görüş Oluşturma ve Raporlama, 18/03/2014 tarihli ve 28945 sayılı Resmi Gazete (Güncel versiyonu için bakınız www.kgk.gov.tr)

BDS 701 Kilit Denetim Konularının Bağımsız Denetçi Raporunda Bildirilmesi, 09/03/2017 tarihli ve 30002 sayılı Resmi Gazete (Güncel versiyonu için bakınız www.kgk.gov.tr) 
BDS 720 Bağımsız Denetçinin Diğer Bilgilere İlişskin Sorumlulukları, 14/03/2014 tarihli ve 28941 sayılı Resmi Gazete (Güncel versiyonu için bakınız www.kgk.gov.tr)

BDS 800 Özel Hususlar - Özel Amaçlı Çerçevelere Göre Hazırlanan Finansal Tabloların Bağımsız Denetimi, 09/04/2014 tarihli ve 28967 sayılı Resmi Gazete (Güncel versiyonu için bakınız www.kgk.gov.tr)

BDS 805 Özel Hususlar - Tek Bir Finansal Tablonun Bağımsız Denetimi ile Finansal Tablolardaki Belirli Unsurların, Hesapların veya Kalemlerin Bağımsız Denetimi, 24/04/2014 tarihli ve 28981 sayılı Resmi Gazete (Güncel versiyonu için bakınız www.kgk.gov.tr)

Bağımsız Denetim Yönetmeliği, 26/12/2012 tarihli ve 28509 sayılı Resmi Gazete (Güncel versiyonu için bakınız www.kgk.gov.tr) 